\title{
Geochemical study of the vertebrate assemblage zones of the Santa Maria Supersequence (Middle to Late Triassic), Paraná Basin, Brazil
}

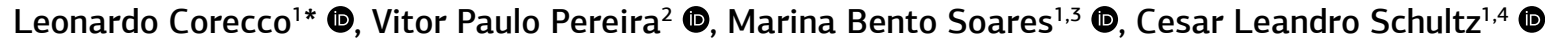

\begin{abstract}
The Middle-Upper Triassic section of the Paraná Basin is included in the Santa Maria Supersequence. This stratigraphic unit is classified as a second-order Supersequence, being subdivided into three third-order sequences in which four Assemblage Zones (AZ) based on tetrapods are recognized. In this work, chemical analyses of fossils and hosting rocks of each $\mathrm{AZ}$ were performed in order to verify whether the geochemical patterns of the rocks could serve to distinguish them even in the absence of fossils. For this purpose, nine samples of fossils and their sedimentary matrices were analyzed, by ICP-MS. The results show that there were changes in the chemical parameters in force at the depositional time of each sequence (and corresponding AZ). In general, the lower portion of the package was deposited under more basic and dry environmental conditions, indicated by the $\mathrm{Ca}$ and $\mathrm{Ba}$ concentrations found in the rocks and bones that contains them. By its turn, the top of the section is characterized by more acid and humid conditions, evidenced by $\mathrm{Al}, \mathrm{Si}$, and $\mathrm{Sr}$ increase. Such a geochemical shift from dry to humid conditions occurred just at the beginning of the Late Triassic and is probably related to the Carnian Pluvial Episode.
\end{abstract}

KEYWORDS: biostratigraphy; paleoclimatology; Gondwana; Carnian Pluvial Episode.

\section{INTRODUCTION}

The Paraná Basin (PB) is filled with an 8,000 m thick sedimentary package. This package does not display a depositional continuity, but polycyclic events resulting from successive sedimentation episodes related to the tectonic events that hit the SW portion of the Gondwana (Milani 1997, Milani et al. 1998). The Middle-Upper Triassic strata (Santa Maria Supersequence SMS sensu Zerfass et al. 2003, Horn et al. 2014, Horn et al. 2018a, 2018 b) that occurs only in Rio Grande do Sul State (Fig. 1) are worldwide recognized by their vertebrate fossil content. It includes Synapsida - dicynodonts and cynodonts (taxa containing the sister-group of mammals) — and Diapsida — rhynchosaurs and archosaurs, including the first dinosaur representatives (Schultz et al. 2000, Langer et al. 2007).

\footnotetext{
${ }^{1}$ Programa de Pós-graduação de Geociências, Instituto de Geociências, Universidade Federal do Rio Grande do Sul - Porto Alegre (RS), Brazil. E-mails: leocorecco@gmail.com, marina.soares@mn.ufrj.br, cesar.schultz@ufrgs.br

${ }^{2}$ Departamento de Mineralogia e Petrologia, Instituto de Geociências, Universidade Federal do Rio Grande do Sul - Porto Alegre (RS), Brazil. E-mail: vitor.pereira@ufrgs.br

${ }^{3}$ Departamento de Geologia e Paleontologia, Museu Nacional, Universidade Federal do Rio de Janeiro - Rio de Janeiro (RJ), Brazil.

${ }^{4}$ Departamento de Paleontologia e Estratigrafia, Instituto de Geociências, Universidade Federal do Rio Grande do Sul - Porto Alegre (RS), Brazil.

${ }^{*}$ Corresponding author.
}

These vertebrates are distributed across the sedimentary package in fourAssemblageZones (AZ) named, base-to-top, Dinodontosaurus, Santacruzodon, Hyperodapedon, and Riograndia. Each AZ has its own particular fossiliferous content which has been used to stratigraphically distinguish them in the field (Zerfass et al. 2003, Soares et al.2011, Langer et al.2018). Pavanatto et al. (2018) synthesized the main fossil species of each AZ, namely: Dinodontosaurus AZ dicynodonts (e.g., Dinodontosaurus sp.), Traversodontidae cynodonts (e.g., Massetognathus ochagaviae, Schmitt et al. 2019) and rauisuchians (Prestosuchus chiniquensis); Santacruzodon AZ almost exclusively composed of Traversodontidae cynodonts (e.g., Menadon besairei and Santacruzodon hopsoni); Hyperodapedon AZ — predominantly rhynchosaurs (e.g., Hyperodapedon sp.), as well as, Traversodontidae (e.g., Exaeretodon riograndensis), probainognathian cynodonts (e.g., Prozostrodon brasiliensis), and sauropodomorph dinosaur (e.g., Saturnalia tupiniquim); Riograndia AZ — small probainognathian cynodonts (e.g., Riograndia guaibensis, Brasilodon quadrangularis), dicynodonts (Jachaleria candelariensis), as well as, theropod (Guaibasaurus candelariensis) and "prosauropod" (e.g., Unaysaurus tolentinoi) dinosaurs. On the other hand, many outcrops of the Santa Maria Supersequence that occur near the fossiliferous localities do not contain fossils, being tentatively associated to a biozone due to its geographical proximity or lithological similarities.

In this context, chemical analyses of the fossils and their sedimentary matrices were carried out, in each biozone, aiming to get geochemical patterns that allow us to characterize and individualize these $\mathrm{AZ}$, even without their particular fossil content. Furthermore, these analyses also sought to obtain some paleoclimatic and paleoenvironmental conditions that 
prevailed at the time of deposition of the rocks that encompass each of the AZ.

\section{GEOLOGICAL SETTING}

The Santa Maria Supersequence (SMS) was defined and subdivided by Zerfass et al. (2003), from base-to-top, in the third-order sequences Santa Maria I, II, and III. Within the first two, four biozones were defined based on its tetrapod occurrences, Dinodontosaurus AZ and Santacruzodon AZ, in SMS I, in addition to Hyperodapedon AZ and Riograndia AZ, in SMS II (Soares et al. 2011). Then, Horn et al. (2014) dismembered the SMS I into two sequences, so that the younger Santacruzodon AZ (Early Carnian age) became incorporated into a fourth third-order sequence, named Santa Cruz. In this context (the presence of a new sequence included between the SMS I and SMS II sequences by Zerfass et al. 2003), Horn et al.
(2014) renamed all the previous sequences from base-to-top as Pinheiros-Chiniquá Sequence (including the Dinodontosaurus AZ - Ladinian), Santa Cruz Sequence (encompassing the Santacruzodon AZ - Early Carnian), Candelária Sequence (encompassing the Hyperodapedon and Riograndia AZ Carnian to Norian), and Mata Sequence (Rhaetian). This latter corresponding to the Santa Maria III Sequence from Zerfass et al. (2003) and the only one devoid of fossil vertebrates.

The vertebrate biozones relative ordering is corroborated via biostratigraphic correlation with similar faunas found in Argentina and Africa. In addition, some absolute ages were obtained from fossiliferous outcrops of the SMS by the U-Pb method in dating detrital zircons (Langer et al. 2018, Philipp et al.2018), indicating ages of 236.1 (Santa Cruz Sequence), 233.23 (Hyperodapedon AZ), and 225.42 Ma (Riograndia AZ). The AZ stratigraphic framework and their respective dating are presented in Figure 2

a)

b)
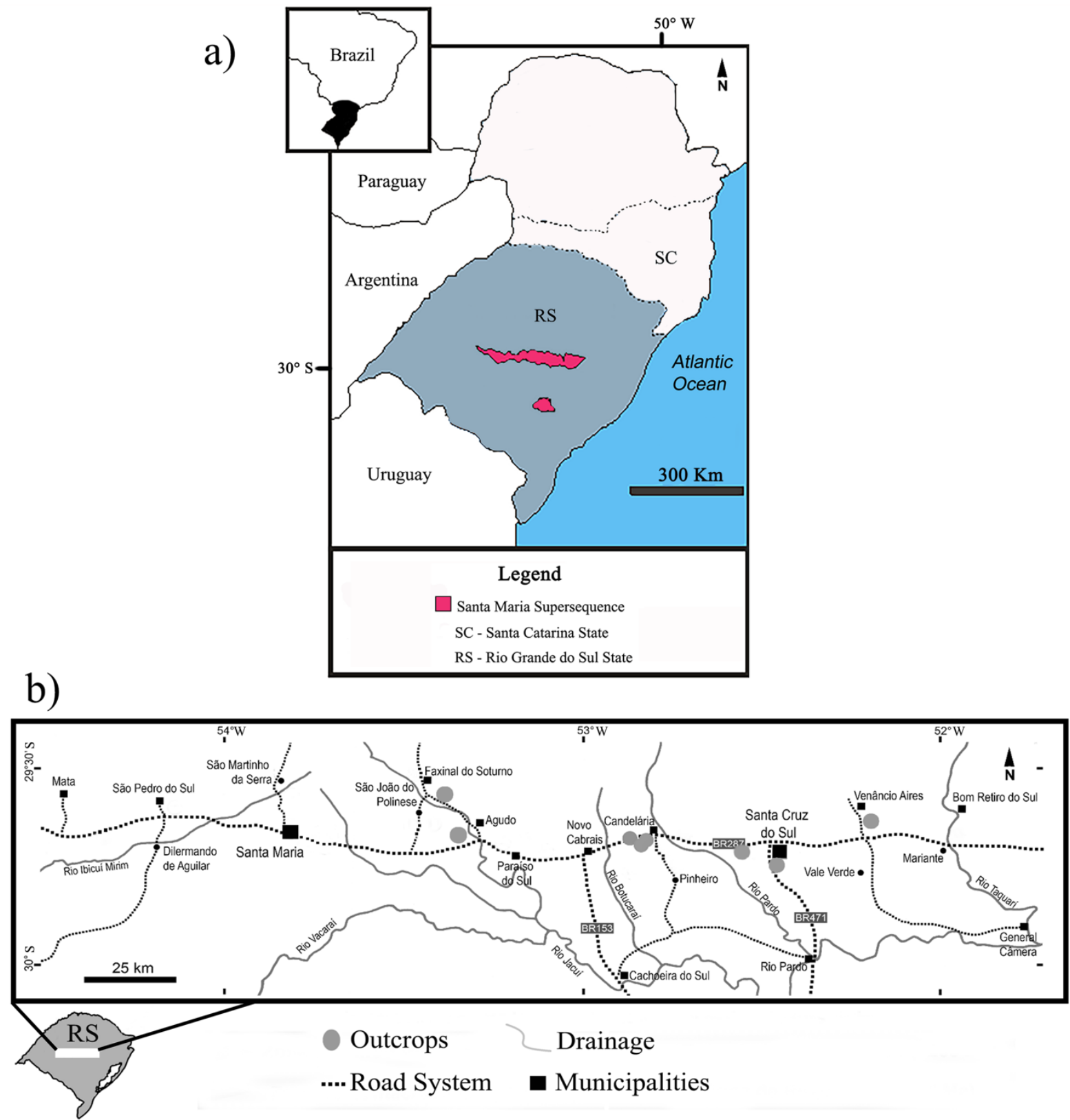

Source: adapted from Martinelli et al. (2017) and Paim (2020).

Figure 1. (A) Geographic map of southern Brazil showing the outcrop belt of the Santa Maria Supersequence from where the studied rocks and fossils were collected (in pink). (B) Localization of the studied outcrops and their Municipalities. 


\section{MATERIALS AND METHODS}

Nine fossil samples and their respective matrices were analyzed by inductively coupled plasma - mass spectrometry (ICP-MS) at Acme Analytical Labs Ltd., located in Vancouver, Canada.

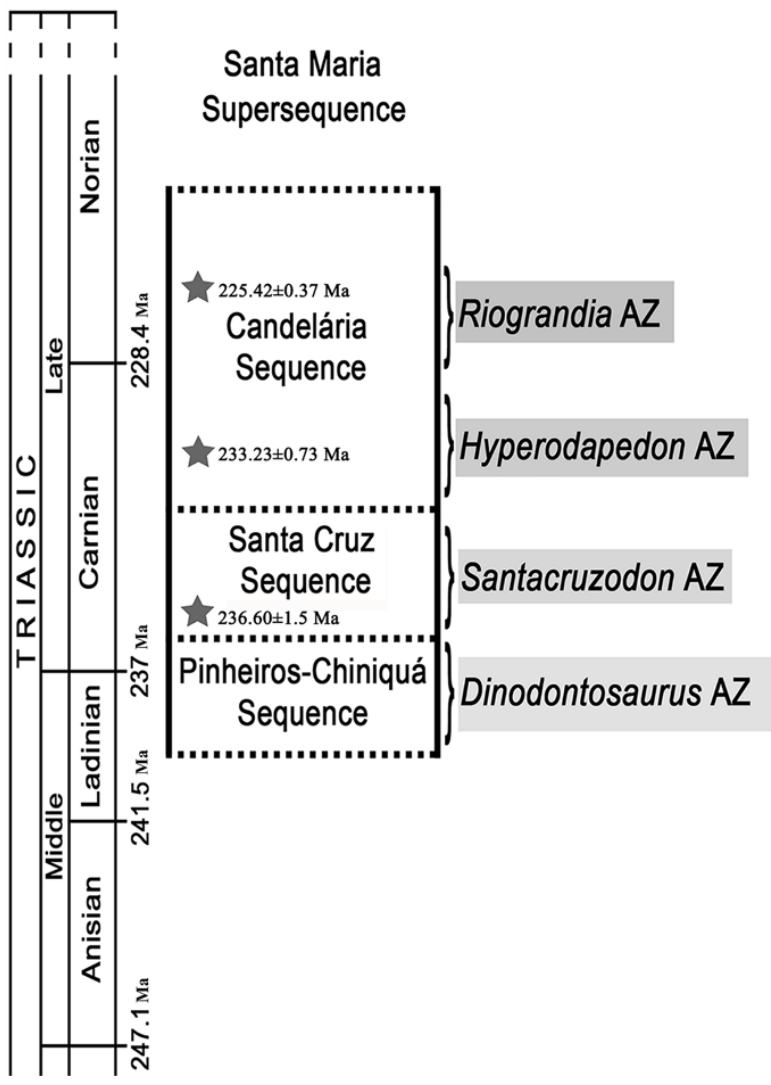

AZ: assemblage zone.

From: adapted from Martinelli et al. (2017), Langer et al. (2018) and Philipp et al. (2018).

Figure 2. The assemblage zones from Santa Maria Supersequence in a schematic view with some detrital zircons dating made by Langer et al. (2018) and Philipp et al. (2018).
The analyzed fossils belong to the Paleovertebrate Section of the Geosciences Institute of the Universidade Federal do Rio Grande do Sul collection (UFRGS-PV-T), as well as, to the Museu Municipal Aristides Carlos Rodrigues collection (MMACR-PV-T), from Candelária, Rio Grande do Sul. The fossils' description and their provenance are presented in Table 1.

For the correlation between the chemical elements (Pearson's Correlation), Excel Software (2010) was used. The results with positive (direct correlation) or negative values (inverse correlation), higher than 0.7 , were considered significant and made it possible to group chemical elements with similar geochemical behavior.

\section{RESULTS}

Here were considered the chemical analysis results of the major and trace elements that have relatively high contents and were contained in the sedimentary matrices and the fossil bones. Despite the number of samples for each AZ not being expressive, it was possible to identify and differentiate the different biostratigraphic units according to their geochemical data. It suggests that the same result can be obtained in the outcrops that do not present the characteristic fossil content of any biozone. The distinction of the AZ sediments composition, from arithmetic means, is synthesized in Table 2.

The distinct composition of the AZ bones, from arithmetic means, is synthesized in Table 3.

The most relevant data analyses that allow to individualize each $\mathrm{AZ}$ are described below. The sedimentary rock results are described first, followed by fossil bones.

\section{Chemical elements analyses in sedimentary rocks}

\section{Dinodontosaurus AZ}

We analyzed rock matrices of this biozone associated with one rauisuchian (Prestosuchus chiniquensis) rib and one

Table 1. Description and provenience of the sampling used for geochemical analyses by ICP-MS.

\begin{tabular}{|c|c|c|c|c|c|c|c|c|}
\hline Sample & Fossil & Bone & Seq. & $\mathbf{A Z}$ & Age & Sed. & Locality & Catalog no. \\
\hline O1A, S1A & $\begin{array}{l}\text { Rauisuchia } \\
\text { Prestosuchus }\end{array}$ & Rib & \multirow{2}{*}{$\begin{array}{l}\text { Pinheiros- } \\
\text { Chiniquá }\end{array}$} & \multirow{2}{*}{ Dinodontosaurus } & \multirow{2}{*}{ Ladinian } & \multirow{2}{*}{$\begin{array}{l}\text { Clayey } \\
\text { siltite; } \\
\text { Pelite }\end{array}$} & $\begin{array}{c}\text { Dona } \\
\text { Francisca }\end{array}$ & UFRGS-PV-0629-T \\
\hline $\mathrm{O} 1 \mathrm{~B}, \mathrm{~S} 1 \mathrm{~B}$ & $\begin{array}{l}\text { Dicynodontia } \\
\text { Dinodontosaurus }\end{array}$ & Vertebra & & & & & $\begin{array}{l}\text { Venâncio } \\
\text { Aires }\end{array}$ & UFRGS-PV-0300-T \\
\hline $\mathrm{O} 2 \mathrm{~A}, \mathrm{~S} 2 \mathrm{~A}$ & $\begin{array}{l}\text { Cynodontia } \\
\text { Menadon }\end{array}$ & Lower jaw & \multirow{2}{*}{$\begin{array}{l}\text { Santa } \\
\text { Cruz }\end{array}$} & \multirow{2}{*}{ Santacruzodon } & \multirow{2}{*}{$\begin{array}{l}\text { Carnian } \\
\text { (Base) }\end{array}$} & \multirow{2}{*}{$\begin{array}{l}\text { Clayey } \\
\text { siltite; } \\
\text { Pelite }\end{array}$} & $\begin{array}{l}\text { Santa Cruz } \\
\text { do Sul }\end{array}$ & UFRGS-PV-1165-T \\
\hline $\mathrm{O} 2 \mathrm{~B}, \mathrm{~S} 2 \mathrm{~B}$ & $\begin{array}{l}\text { Undetermined } \\
\text { Cynodontia }\end{array}$ & Skull & & & & & $\begin{array}{c}\text { Venâncio } \\
\text { Aires }\end{array}$ & UFRGS-PV0457-T \\
\hline O3A, S3A & $\begin{array}{l}\text { Cynodont } \\
\text { Exaeretodon }\end{array}$ & Lower jaw & \multirow{3}{*}{$\begin{array}{c}\text { Candelária } \\
\text { (Lower) }\end{array}$} & \multirow{3}{*}{ Hyperodapedon } & \multirow{3}{*}{$\begin{array}{l}\text { Carnian } \\
\text { (Top) }\end{array}$} & \multirow{3}{*}{$\begin{array}{l}\text { Clayey } \\
\text { siltite; } \\
\text { Pelite }\end{array}$} & Agudo & UFRGS-PV-1226-T \\
\hline O3B, S3B & $\begin{array}{l}\text { Rhynchosauria } \\
\text { Hyperodapedon }\end{array}$ & $\mathrm{Rib}$ & & & & & Vale do Sol & UFRGS-PV-1206-T \\
\hline $\mathrm{O} 3 \mathrm{C}, \mathrm{S} 3 \mathrm{C}$ & $\begin{array}{l}\text { Rhynchosauria } \\
\text { Hyperodapedon }\end{array}$ & Skull & & & & & $\begin{array}{l}\text { Santana da } \\
\text { Boa Vista }\end{array}$ & UFRGS-PV-1248-T \\
\hline O4A, S4A & $\begin{array}{l}\text { Dicynodontia } \\
\text { Jachaleria }\end{array}$ & $\mathrm{Rib}$ & \multirow{2}{*}{$\begin{array}{l}\text { Candelária } \\
\text { (Upper) }\end{array}$} & \multirow{2}{*}{ Riograndia } & \multirow{2}{*}{ Norian } & \multirow{2}{*}{$\begin{array}{l}\text { Clayey } \\
\text { siltite; } \\
\text { Pelite }\end{array}$} & Candelária & UFRGS-PV-0540-T \\
\hline O4B, S4B & $\begin{array}{l}\text { Undetermined } \\
\text { Archosaur }\end{array}$ & $\begin{array}{l}\text { Post-cranial } \\
\text { fragments }\end{array}$ & & & & & Candelária & MMACRPV012T \\
\hline
\end{tabular}

ICP-MS: inductively coupled plasma - mass spectrometry; Seq.: sequences; AZ: assemblage zone; Sed.: sediment/matrices. 
dicynodont (Dinodontosaurus sp.) vertebra (see Tab. 1 for details). The geochemical analyses results (Tab. 2) indicated that these rocks have the highest mean values of $\mathrm{Ba}(1,569 \mathrm{ppm})$ and the lowest of $\mathrm{P}(0.06 \%)$.

\section{Santacruzodon AZ}

The host sediment associated with a cynodont jaw (Menadon besairiei) and also a skull of an undetermined species of cynodont enabled us to conclude that the Santacruzodon AZ has the highest average of $\mathrm{Ca}(17.38 \%)$ and $\mathrm{Sn}(2 \mathrm{ppm})$. It also has the lowest values of $\mathrm{Al}$ (5.54\%), $\mathrm{Si}$ (17.84\%), V (30 ppm), $\mathrm{Zn}$ (7 ppm), Rb (70 ppm), Sr (150 ppm), Zr (187 ppm), and $\mathrm{Pb}$ (7 ppm).

\section{Hyperodapedon AZ}

For this AZ, the rock matrices around a cynodont lower jaw (Exaeretodon riograndensis) and a rib and a skull of a rhynchosaur (Hyperodapedon sp.) were analyzed (see Tab. 1 for details). These samples presented a significant number of elements with high average contents $(\mathrm{Na}, \mathrm{Mg}, \mathrm{Al}, \mathrm{Si}, \mathrm{K}, \mathrm{Sc}, \mathrm{Ti}$, $\mathrm{Mn}, \mathrm{Fe}, \mathrm{Co}, \mathrm{Ni}, \mathrm{Cu}, \mathrm{Ga}, \mathrm{Rb}, \mathrm{Sr}, \mathrm{Zr}, \mathrm{Nb}$, and $\mathrm{Pb}$ ). The most relevant contents are $\mathrm{Al}$ (9.18\%), $\mathrm{Si}$ (31.84\%), $\mathrm{Fe}$ (2.28\%), Rb (115 ppm), Sr (889 ppm), Zr (392 ppm), and Pb (46 ppm), as showed in Table 2. A relative high content of $\mathrm{Nb}$ (12 ppm) was detected. According to Nagarajan et al. (2007), Nb's average in sedimentary rocks is $1.90 \mathrm{ppm}$. On the other hand, the associated rocks of this biozone have the lowest contents of F (0.05\%) and Ca (1.05\%).

\section{Riograndia AZ}

We analyzed the host sediments of a dicynodont rib (Jachaleria candelariensis) and an undetermined archosaur post-cranial fragment (see Tab. 1 for details). The results of this AZ indicated the highest content of F (0.41\%), P (2.18\%),
$\mathrm{V}(271 \mathrm{ppm})$, and $\mathrm{Y}$ (585 ppm). The $\mathrm{Y}$ anomaly is highly surprising when compared to the Anders and Grevesse (1989) chondrites average (1.56 ppm). The high values of $\mathrm{Nb}(7 \mathrm{ppm})$ are also anomalous both in relation to the chondrites (246 ppb) and Post-Archean Australian Average Shale (PAAS) (1.90 ppm, Nagarajan et al. 2007) standards. Despite the fact that $\mathrm{Nb}$ can be relatively concentrated in comparison to the PAAS pattern, this biozone has the lowest contents of this element. In addition, the Riograndia AZ has the lowest values of Fe (1.14\%) and $\mathrm{Ba}$ (573 ppm).

The characteristic elements of each AZ, in the host rocks around the fossils, are presented in Table 4.

\section{Chemical elements analyses in bones}

\section{Dinodontosaurus AZ}

The fossil bones of this biozone presented the highest average contents of $\mathrm{Ca}(36 \%)$. Otherwise, they have the lowest contents of F, Na, Al, Si, P, Sc, Ti, V, Cr, Co, Ni, Cu, Zn, Ga, As, $\mathrm{Rb}, \mathrm{Sr}, \mathrm{Y}, \mathrm{Zr}, \mathrm{Nb}, \mathrm{W}$, and $\mathrm{Pb}$. The most relevant values are those of Si (2.28\%), P (2.91\%), Sr (735 ppm), and Y (396 ppm).

\section{Santacruzodon AZ}

In this biozone, the bones registered high contents of $\mathrm{Be}$, $\mathrm{Cr}, \mathrm{Mn}, \mathrm{Fe}, \mathrm{Co}, \mathrm{Ga}, \mathrm{As}, \mathrm{Y}, \mathrm{Ba}, \mathrm{W}$, and $\mathrm{Pb}$. The most relevant values are those of $\mathrm{Cr}(0.01 \%), \mathrm{Mn}(2.05 \%)$, As (364 ppm), $\mathrm{Y}(2,358 \mathrm{ppm})$, and $\mathrm{Ba}(27,466 \mathrm{ppm})$. On the other hand, this $\mathrm{AZ}$ has the lowest contents of $\mathrm{K}(0.1 \%)$.

\section{Hyperodapedon $A Z$}

The fossils of this AZ had the highest average contents of $\mathrm{Na}$, $\mathrm{Al}, \mathrm{Sc}, \mathrm{Ti}, \mathrm{Ni}, \mathrm{Rb}$, and $\mathrm{Sr}$. The most relevant values are those of $\mathrm{Al}(0.91 \%)$ and $\mathrm{Sr}(5,939 \mathrm{ppm})$. This AZ presented the lowest average values of $\mathrm{Be}(2 \mathrm{ppm}), \mathrm{Ca}(31.14 \%)$, and $\mathrm{Mn}(0.34 \%)$.

Table 2. Average contents of the main elements analyzed on rock matrices for each AZ*.

\begin{tabular}{|c|c|c|c|c|c|c|c|c|c|c|c|c|}
\hline & \multirow{2}{*}{$\mathbf{A Z}$} & \multicolumn{4}{|c|}{$(\%)$} & \multicolumn{7}{|c|}{ (ppm) } \\
\hline & & Al & $\mathbf{S i}$ & $\mathbf{P}$ & $\mathbf{C a}$ & $\mathbf{R b}$ & Sr & $\mathbf{Y}$ & $\mathbf{Z r}$ & $\mathbf{N b}$ & $\mathbf{B a}$ & $\mathbf{P b}$ \\
\hline Top & Riograndia & 6.59 & 29.41 & 2.18 & 6.49 & 77.05 & 617.30 & 584.90 & 386.90 & 7.45 & 573.00 & 22.20 \\
\hline \multirow[t]{2}{*}{$\uparrow$} & Hyperodapedon & 9.18 & 31.84 & 0.10 & 1.05 & 115.37 & 889.47 & 34.20 & 392.57 & 12.50 & 795.00 & 46.03 \\
\hline & Santacruzodon & 5.54 & 17.84 & 0.095 & 17.38 & 70.75 & 150.80 & 64.00 & 187.00 & 7.60 & $1,367.50$ & 7.65 \\
\hline Base & Dinodontosaurus & 7.42 & 24.78 & 0.06 & 9.00 & 93.65 & 197.10 & 38.90 & 294.50 & 11.05 & $1,569.50$ & 10.00 \\
\hline
\end{tabular}

${ }^{*}$ The highest contents are in bold and the lowest, in italics; AZ: assemblage zone.

Table 3. Average contents of the main elements of bone fragments analyzed for each AZ*

\begin{tabular}{lccccc:cccccccc}
\hline & $\mathbf{A Z}$ & \multicolumn{4}{c}{$(\mathbf{\%})$} & \multicolumn{8}{c}{ (ppm) } \\
\cline { 2 - 13 } & $\mathbf{A l}$ & $\mathbf{S i}$ & $\mathbf{P}$ & $\mathbf{C a}$ & $\mathbf{V}$ & $\mathbf{Z n}$ & $\mathbf{A s}$ & $\mathbf{S r}$ & $\mathbf{Y}$ & $\mathbf{Z r}$ & $\mathbf{B a}$ & $\mathbf{P b}$ \\
\hline Top & Riograndia & 0.75 & $\mathbf{2 . 7 9}$ & $\mathbf{1 0 . 3 3}$ & 34.78 & 683.00 & 32.00 & 265.50 & $1,923.60$ & $1,756.35$ & $\mathbf{1 3 0 . 4 5}$ & $1,537.50$ & 115.20 \\
$\mathbf{4}$ & Hyperodapedon & $\mathbf{0 . 9 1}$ & 2.30 & 7.67 & 31.14 & 141.00 & 29.33 & 292.10 & $\mathbf{5 , 9 3 9 . 3 3}$ & $1,104.67$ & 115.37 & $17,193.67$ & 111.33 \\
& & & & & & & & & & & & & \\
& Santacruzodon & 0.80 & 2.44 & 7.35 & 31.25 & 410.00 & 24.00 & $\mathbf{3 6 4 . 3 0}$ & $1,449.55$ & $\mathbf{2 , 3 5 8 . 2 5}$ & 80.05 & $\mathbf{2 7 , 4 6 6 . 0 0}$ & $\mathbf{2 0 3 . 0 5}$ \\
& & & & & & & & & & & & & \\
Base & Dinodontosaurus & 0.62 & 2.28 & 2.91 & 35.83 & 95.50 & 14.00 & 80.65 & 735.35 & 396.90 & 33.35 & $19,301.00$ & 32.40 \\
\hline
\end{tabular}

*The highest contents are in bold and the lowest, in italics; AZ: assemblage zone. 


\section{Riograndia AZ}

It is possible to stand out, for this $\mathrm{AZ}$, the highest average contents of $\mathrm{Si}, \mathrm{P}, \mathrm{K}, \mathrm{V}, \mathrm{Cu}, \mathrm{Zn}$, and $\mathrm{Nb}$, highlighting the expressive absolute values of $\mathrm{Si}(2.79 \%), \mathrm{P}$ (10\%), and V (683 ppm). However, this AZ has the lowest average contents of $\mathrm{Mg}(0.14 \%), \mathrm{Fe}(0.18 \%)$, and $\mathrm{Ba}(1,537 \mathrm{ppm})$.

The characteristic elements of each AZ in the fossil bones are presented in Table 5 .

\section{DISCUSSION}

Some of the analyzed elements could be used to differentiate AZ hosting rocks, not by their high or low contents, but by their standard deviation $(\mathrm{SD} ; \sigma)$. The SD represents the sample group homogeneity (Bland and Altman 1996), e.g., the $\mathrm{F}(\sigma=0.0007)$ and the $\mathrm{P}(\sigma=0.03)$ in the Dinodontosaurus AZ; the $\mathrm{K}(\sigma=0.20)$ in the Hyperodapedon $\mathrm{AZ}$, and $\mathrm{Fe}(\sigma=0.0)$ in the Riograndia AZ. High standard deviation values indicate that the sample group is heterogeneous or inconstant (Bland and Altman 1996, Walker $1931)$, e.g., the $\mathrm{Ba} \mathrm{SD}(\sigma=1,447.45)$ and $\operatorname{Sr}(\sigma=1,283.83)$ in Hyperodapedon AZ. Thus, when analyzing other outcrops

Table 4. Differences in the composition of the sedimentary matrices of each assemblage zone. The concentrations of elements (major and trace) of certain biozones when compared to the others are highlighted.

\begin{tabular}{lcc}
\hline \multirow{2}{*}{$\mathbf{A Z}$} & \multicolumn{2}{c}{ Sedimentary matrices } \\
\cline { 2 - 3 } $\begin{array}{l}\text { Riograndia } \\
\text { AZ }\end{array}$ & $\mathrm{Be}, \mathrm{F}, \mathrm{P}, \mathrm{V}, \mathrm{Zn}, \mathrm{As}, \mathrm{Y}$ & $\mathbf{M g}, \mathrm{Mn}, \mathrm{Fe}, \mathrm{Co}, \mathrm{Nb}$, \\
& $\mathrm{Sn}, \mathrm{Ba}$ \\
Hyperodapedon & $\mathrm{Na}, \mathrm{Mg}, \mathbf{A l}, \mathbf{S i}, \mathrm{K}, \mathrm{Sc}$, \\
AZ & $\mathrm{Ti}, \mathrm{Mn}, \mathbf{F e}, \mathrm{Co}, \mathbf{N i}$, \\
& $\mathrm{Cu}, \mathrm{Ga}, \mathbf{R b}, \mathrm{Sr}, \mathbf{Z r}$, & $\mathbf{F}, \mathbf{P}, \mathbf{C a}, \mathrm{Y}$ \\
Nb, W, Pb & \\
$\begin{array}{l}\text { Santacruzodon } \\
\text { AZ }\end{array}$ & $\mathrm{Ca}, \mathrm{Sn}$ & $\mathrm{Be}, \mathrm{Na}, \mathrm{Al}, \mathrm{Si}, \mathrm{K}, \mathrm{Sc}, \mathrm{Cr}, \mathrm{Ni}, \mathrm{Cu}, \mathrm{Zn}$, \\
& & $\mathbf{A s}, \mathrm{Rb}, \mathrm{Sr}, \mathrm{Zr}, \mathrm{W}, \mathrm{Pb}$ \\
$\begin{array}{l}\text { Dinodontosaurus } \\
\text { AZ }\end{array}$ & $\mathrm{Ba}$ & $\mathrm{Be}, \mathrm{P}, \mathrm{Sn}$ \\
\hline
\end{tabular}

*In bold the elements that make it possible to individualize each biostratigraphic units; AZ: assemblage zone.

Table 5. Differences in fossil bones fragments compositions (major and trace concentrations) of each assemblage zone when compared to the others.

\begin{tabular}{|c|c|c|}
\hline \multirow{2}{*}{$\mathbf{A Z}$} & \multicolumn{2}{|c|}{ Bones } \\
\hline & Maximum & Minimum \\
\hline $\begin{array}{l}\text { Riograndia } \\
\text { AZ }\end{array}$ & $\begin{array}{c}\mathrm{F}, \mathrm{Si}, \mathrm{P}, \mathrm{K}, \mathrm{V}, \mathrm{Cu} \\
\mathrm{Zn}, \mathrm{Nb}\end{array}$ & $\mathrm{Mg}, \mathrm{Fe}, \mathrm{Ba}$ \\
\hline $\begin{array}{l}\text { Hyperodapedon } \\
\mathrm{AZ}\end{array}$ & $\begin{array}{c}\mathrm{Na}, \mathrm{Al}, \mathrm{Sc}, \mathrm{Ti}, \mathrm{Ni} \\
\mathrm{Rb}, \mathrm{Sr}\end{array}$ & $\mathrm{Be}, \mathrm{Ca}, \mathrm{Mn}$ \\
\hline $\begin{array}{l}\text { Santacruzodon } \\
\text { AZ }\end{array}$ & $\begin{array}{l}\mathrm{Be}, \mathrm{Cr}, \mathrm{Mn}, \mathrm{Fe}, \mathrm{Co}, \\
\mathrm{Ga}, \mathrm{As}, \mathrm{Y}, \mathrm{Ba}, \mathrm{W}, \mathrm{Pb}\end{array}$ & $\mathrm{K}$ \\
\hline $\begin{array}{l}\text { Dinodontosaurus } \\
\text { AZ }\end{array}$ & $\mathrm{Mg}, \mathrm{Ca}$ & $\begin{array}{c}\text { F, Na, Al, Si, P, Sc, } \\
\text { Ti, V, Cr, Ni, Cu, Zn, } \\
\text { Ga, As, Rb, Sr, Y, Zr, } \\
\text { Nb, W, Pb }\end{array}$ \\
\hline
\end{tabular}

AZ: assemblage zone. in future works and encountering those high SD results, the researcher may have some notion from which AZ the samples came through. So, those SD values (high - heterogeneity and low - homogeneity) could also be used as an identification criterion for these biozones. It is applicable provided that the sample $n$ is representative, since their values are associated to the number of samples analyzed. The SD significance increases as sampling increases and vary according to the analyses results.

Tables 6 and 7 contain, in bold, the lowest (sample homogeneity) and the highest SD values (sample heterogeneity), in red.

$\mathrm{P}$ and the $\mathrm{K}$ are relatively depleted, in relation to the average values, in both, sediments and bones of the lowermost AZ (Dinodontosaurus and Santacruzodon). P is more depleted in Dinodontosaurus AZ and K in Santacruzodon. In the Hyperodapedon $\mathrm{AZ}, \mathrm{Na}, \mathrm{Al}, \mathrm{Sc}, \mathrm{Ti}, \mathrm{Ni}, \mathrm{Rb}$, and $\mathrm{Sr}$ have high average contents, but Ca values are low. This behavior occurs in both sediments and bones. Riograndia AZ has high average contents (in both matrices and bones) of F, P, V, and $\mathrm{Zn}$. However, $\mathrm{Mg}, \mathrm{Fe}$, and $\mathrm{Ba}$ have low values compared to the other biozones.

The high contents of $\mathrm{Al}, \mathrm{Si}, \mathrm{Ti}, \mathrm{Fe}, \mathrm{Ni}, \mathrm{Rb}, \mathrm{Zr}$, and $\mathrm{Nb}$ allowed to individualize solely the Hyperodapedon $\mathrm{AZ}$ sediments. This AZ can also be differentiated by the lowest contents of F, $\mathrm{P}$, and $\mathrm{Ca}$. This particular composition from Hyperodapedon AZ can be observed in Tables 4 and 8 .

The Riograndia's AZ sediments can be differentiated by the low content of $\mathrm{Mg}$, meanwhile, those from Santacruzodon AZ, by the low content of As (Tabs. 4 and 8 ).

All the analyzed samples, regardless of the Sequence/AZ they belong to, correspond to red silt-clay sedimentary rocks. The sedimentary facies analyses made by Horn et al. (2018a) at SMS enabled these authors to identify two dominant associations across the package:

- dry mudflat facies (loess deposits);

- sheet delta facies (underwater deposits).

A dry mudflat association characterizes the PinheirosChiniquá (Dinodontosaurus AZ) and the Santa Cruz (Santacruzodon AZ) Sequences. A sheet delta association, on the other hand, characterizes the Candelária Sequence (Hyperodapedon and Riograndia AZs). In this context, the faciological variation of the lowermost portion of the Candelária Sequence indicates a change from arid to humid conditions. Similar climatic changes were described by Zeng et al. (2019) for the Mungaroo Formation (Middle-Upper Triassic, Australia), where the climate changed from temperate and warm to humid and monsoonal. Thus, the existence of contemporary higher humidity events, in opposite portions of Gondwana, was found. Besides, the paleontological and sedimentological studies carried out by Zeng et al. (2019) detected different intensities in the megamonsoon events that hit the Northwest Shelf of Australia, during the Middle Triassic. The Mungaroo Formation records higher humidity and the Brigadier Formation, overlapping, would mark a decrease in those monsoonal effects (Zeng et al. 2019). Something similar was recorded in the passage from Hyperodapedon $\mathrm{AZ}$ to 
Riograndia AZ, in Brazil. Corroborating the sedimentological data by Horn et al. (2018a, 2018b), the high contents of $\mathrm{Al}, \mathrm{Si}$, and $\mathrm{Fe}$ recorded on Hyperodapedon's $\mathrm{AZ}$ sediments (Carnian) indicate a humidity peak. This peak, according to the dating (233.23 Ma.), could be related to the global event named "Wet Intermezzo" or Carnian Pluvial Episode (CPE), whose stipulated age is between 230 and $232 \mathrm{Ma}$. (Furin et al. 2006, Ogg 2015, Benton et al. 2018). In the Riograndia's AZ

Table 6. Standard deviation (major elements) obtained by ICP-MS analyses in sediment samples of assemblage zones from Santa Maria Supersequence.

\begin{tabular}{|c|c|c|c|c|}
\hline \multirow{3}{*}{ Elements(\%) } & Base & & $\longrightarrow$ & Top \\
\hline & \multicolumn{4}{|c|}{$\mathbf{A Z}(\sigma)$} \\
\hline & Dinodontosaurus & Santacruzodon & Hyperodapedon & Riograndia \\
\hline $\mathrm{F}$ & $\sigma=0.0007$ & $\sigma=0.016$ & $\sigma=0.01$ & $\sigma=0.46$ \\
\hline $\mathrm{Mg}$ & $\sigma=0.11$ & $\sigma=\mathbf{0 . 5 3}$ & $\sigma=0.09$ & $\sigma=0.05$ \\
\hline $\mathrm{Al}$ & $\sigma=2.52$ & $\sigma=5.79$ & $\sigma=0.37$ & $\sigma=1.10$ \\
\hline $\mathrm{Si}$ & $\sigma=9.97$ & $\sigma=18.84$ & $\sigma=1.63$ & $\sigma=6.49$ \\
\hline $\mathrm{P}$ & $\sigma=0.03$ & $\sigma=0.06$ & $\sigma=0.06$ & $\sigma=2.56$ \\
\hline $\mathrm{K}$ & $\sigma=0.58$ & $\sigma=1.35$ & $\sigma=0.20$ & $\sigma=0.38$ \\
\hline $\mathrm{Ca}$ & $\sigma=11.29$ & $\sigma=23.41$ & $\sigma=0.45$ & $\sigma=6.08$ \\
\hline $\mathrm{Ti}$ & $\sigma=0.13$ & $\sigma=\mathbf{0 . 2 8}$ & $\sigma=0.02$ & $\sigma=0.05$ \\
\hline $\mathrm{Fe}$ & $\sigma=0.49$ & $\sigma=1.43$ & $\sigma=0.26$ & $\sigma=0.00$ \\
\hline
\end{tabular}

*The highest contents are in bold and the lowest, in italic; ICP-MS: inductively coupled plasma - mass spectrometry; AZ: Assemblage Zones.

Table 7. Standard deviation (trace elements) obtained by ICP-MS analyses in sediment samples of Assemblage Zones from Santa Maria Supersequence.

\begin{tabular}{|c|c|c|c|c|}
\hline \multirow{3}{*}{ Elements (ppm) } & Base & 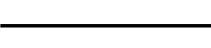 & $\longrightarrow$ & Top \\
\hline & \multicolumn{4}{|c|}{$\mathbf{A Z}(\sigma)$} \\
\hline & Dinodontosaurus & Santacruzodon & Hyperodapedon & Riograndia \\
\hline $\mathrm{V}$ & $\sigma=0.71$ & $\sigma=20.51$ & $\sigma=18.33$ & $\sigma=323.34$ \\
\hline $\mathrm{Zn}$ & $\sigma=1.41$ & $\sigma=6.36$ & $\sigma=3.79$ & $\sigma=17.68$ \\
\hline $\mathrm{Ga}$ & $\sigma=4.17$ & $\sigma=9.12$ & $\sigma=1.08$ & $\sigma=0.35$ \\
\hline As & $\sigma=1.63$ & $\sigma=0.21$ & $\sigma=2.51$ & $\sigma=51.69$ \\
\hline $\mathrm{Rb}$ & $\sigma=29.63$ & $\sigma=73.47$ & $\sigma=14.89$ & $\sigma=8.41$ \\
\hline $\mathrm{Sr}$ & $\sigma=31.40$ & $\sigma=10.47$ & $\sigma=1,283.83$ & $\sigma=507.42$ \\
\hline $\mathrm{Y}$ & $\sigma=25.17$ & $\sigma=46.10$ & $\sigma=5.57$ & $\sigma=704.42$ \\
\hline $\mathrm{Zr}$ & $\sigma=149.62$ & $\sigma=192.90$ & $\sigma=64.73$ & $\sigma=102.11$ \\
\hline $\mathrm{Nb}$ & $\sigma=3.61$ & $\sigma=7.92$ & $\sigma=0.53$ & $\sigma=0.92$ \\
\hline $\mathrm{Ba}$ & $\sigma=1,447.45$ & $\sigma=1,117.94$ & $\sigma=548.51$ & $\sigma=41.01$ \\
\hline $\mathrm{Pb}$ & $\sigma=3.68$ & $\sigma=4.88$ & $\sigma=\mathbf{5 9 . 7 3}$ & $\sigma=23.48$ \\
\hline
\end{tabular}

*The highest contents are in bold and the lowest, in italic; ICP-MS: inductively coupled plasma - mass spectrometry; AZ: Assemblage Zones.

Table 8. ICP-MS results for sediment samples of assemblage zones from Santa Maria Supersequence, based on calculated standard deviation.

\begin{tabular}{|c|c|c|c|c|c|c|c|c|c|c|c|c|c|c|}
\hline & \multirow{2}{*}{$\mathbf{A Z}$} & \multicolumn{8}{|c|}{ (\%) } & \multicolumn{5}{|c|}{ (ppm) } \\
\hline & & $\mathbf{F}$ & Mg & Al & $\mathbf{S i}$ & $\mathbf{P}$ & $\mathbf{C a}$ & $\mathbf{T i}$ & $\mathbf{F e}$ & $\mathbf{N i}$ & As & $\mathbf{R b}$ & $\mathbf{Z r}$ & $\mathbf{N b}$ \\
\hline \multirow{3}{*}{ Top } & \multirow{3}{*}{ Riograndia } & 0.740 & 0.58 & 5.81 & 24.82 & 3.99 & 10.79 & 0.26 & 1.14 & 4.8 & 82.2 & 71.1 & 314.7 & 6.8 \\
\hline & & 0.086 & 0.52 & 7.37 & 34.00 & 0.36 & 2.19 & 0.32 & 1.14 & 3.7 & 9.1 & 83.0 & 459.1 & 8.1 \\
\hline & & 0.048 & 0.84 & 9.03 & 32.68 & 0.06 & 0.77 & 0.44 & 2.10 & 5.7 & 3.7 & 113.0 & 436.2 & 12.9 \\
\hline \multirow[t]{4}{*}{$\uparrow$} & \multirow[t]{2}{*}{ Hyperodapedon } & 0.045 & 0.80 & 8.91 & 32.87 & 0.07 & 0.81 & 0.45 & 2.15 & 9.0 & 7.1 & 101.8 & 423.3 & 11.9 \\
\hline & & 0.063 & 0.97 & 9.60 & 29.96 & 0.17 & 1.57 & 0.47 & 2.58 & 7.4 & 2.2 & 131.3 & 318.2 & 12.7 \\
\hline & \multirow{2}{*}{ Santacruzodon } & 0.033 & 0.27 & 1.44 & 4.52 & 0.14 & 33.93 & 0.07 & 0.42 & 1.4 & 1.9 & 18.8 & 50.6 & 2.0 \\
\hline & & 0.055 & 1.02 & 9.63 & 31.16 & 0.05 & 0.82 & 0.46 & 2.44 & 5.0 & 1.6 & 122.7 & 323.4 & 13.2 \\
\hline \multirow{2}{*}{ Base } & \multirow{2}{*}{ Dinodontosaurus } & 0.054 & 0.84 & 9.20 & 31.83 & 0.04 & 1.02 & 0.46 & 2.27 & 4.4 & 1.4 & 114.6 & 400.3 & 13.6 \\
\hline & & 0.055 & 0.68 & 5.64 & 17.73 & 0.08 & 16.98 & 0.28 & 1.58 & 2.6 & 3.7 & 72.7 & 188.7 & 8.5 \\
\hline
\end{tabular}

*The highest contents are in bold and the lowest, in italic; ICP-MS: inductively coupled plasma - mass spectrometry; AZ: Assemblage Zones. 
sediments, there is a reduction in these elements content, although they remain relatively high. It could indicate that the CPE decreased its intensity.

The rock matrices of the Dinodontosaurus and Santacruzodon $\mathrm{AZ}$ are enriched in $\mathrm{Ca}, \mathrm{Sn}$, and $\mathrm{Ba}$. According to Brookings (1988), these elements are concentrated in more basic $\mathrm{pH}$ conditions $(\approx 7.83$ and 14$)$, indicating more arid environmental conditions. The sediments of Hyperodapedon and Riograndia, on the other hand, are enriched in $\mathrm{Al}, \mathrm{Si}$, and $\mathrm{Sr}$. The first two elements are characteristic of minerals that crystallized under broad $\mathrm{pH}$ conditions $(\approx 1$ to 12.5$)$. Meantime, also according to Brookins (1988), minerals that contain $\mathrm{Sr}$ are generally formed under acid to slightly basic conditions ( $\approx 1$ to 7.32 ). It could indicate an acidification followed by a humidity increase across the SMS depositional evolution.

The highest levels of $\mathrm{Si}$ in studied bones are recorded in Riograndia AZ (2.79\%) and not in Hyperodapedon (2.3\%). This contradicts the previous observations made by Reichel et al. (2005) and Horn (2013) that detected chalcedony (with diagenetic particularity) only in Santacruzodon's sediment. These authors used thin sections to carry these observations. The relatively high levels of Si in Riograndia AZ indicate more acid conditions in weather profiles. It could be associated to many factors, including, in this case, leaching by acid rains. Acid rains at that moment would be an effect of the Large Igneous Provinces (LIPs) volcanism related to the climatic changes, as described by Benton (2018), Benton et al. (2018) and Zeng et al. (2019). Preto et al. (2010), Benton and Newell (2014), and Benton et al. (2018), specially associated to the warming and increased rainfall, to the end Triassic mass extinctions. For Benton (1986), there was more than one extinction event during the end of the Triassic period. The first one would have occurred during the Carnian and the second, in Norian (around 17 to $20 \mathrm{Ma}$. after the first). The first extinction event, although smaller, was subdivided into two sub events. One with low intensity that affects the ammonites (at the beginning of Carnian) and the second one, larger, that affects some tetrapod groups (at the end of Carnian).

A Wrangellian large igneous province (WLIP), associated with rifting at the beginning of Pangea's breaking up and to megamonsoon events, would have been responsible for triggering the CPE (Zeng et al. 2019). Initially, the CPE was interpreted as a high humidity episode, though shortlived (Preto and Hinnov 2003, Rigo et al. 2007), in regional scale, restricted only to the European plate and the Tethys Ocean (Simms and Ruffell 1989, 1990, Simms et al. 1995). Meantime, recent studies (Preto et al. 2010, Benton and Newell 2014, Cheng et al. 2019, Horn et al. 2018a, 2018b, Zeng et al. 2019) have been demonstrating that its occurrence was in global scale. The CPE was detected in sediments from many different places around the world, such as, in the SW of the United States (Prochnow et al. 2006, Lucas and Tanner 2018), Australia (Zeng et al. 2019), and Brazil (Horn et al. 2018a). Thus, it covers both the northern and the southern hemispheres. Benton et al. (2018) correlate a rapidly climatic changing event (dry-wet-dry) that supposedly happened in the Carnian, with the dinosaur's diversification. The analyzed sediments of Zeng et al. (2019), in Mungaroo Formation (Australia), reflects relatively rapid deposition associated to a strong hydrodynamic condition. This suggests that the megamonsoon would have happened in a relatively short, though expressive, time, at least in that region. Although these evidences point to a rapid great humidity event in the Carnian, Ogg (2015) suggests that biostratigraphic calibrations (in both marine and continental environments) and radioisotopic dating should be made to delimitate the real duration of this episode.

In relation to the variations in the $\mathrm{Mg}$ and $\mathrm{Al}$ contents, $\mathrm{Mg}$ is characterized by its high mobility, meanwhile Al, by its low mobility, both in weather profiles (White 2013). In sediments under Standard Ambient Temperature and Pressure (SATP), lower values of $\mathrm{Mg}$ (in comparison to $\mathrm{Al}$ ) are expected. If the $\mathrm{Al}$ contents also quickly decrease, in comparison to the sediments average values (as the North American Shale Composite - NASC pattern of Gromet et al. (1984); 2.86\% $\mathrm{Mg}$ and $16.90 \% \mathrm{Al})$, it indicates that the weathering processes were very intense (Sheldon and Tabor 2009). In the studied samples, the $\mathrm{Mg}(0.87 \%)$ and $\mathrm{Al}(9.18 \%)$ contents found in Hyperodapedon's AZ sediments are low, in comparison to the average contents of the NASC pattern. This suggests a very intense weathering process (Benton and Newell 2014) that can be associated with higher humidity episodes.

A synthetic model with the most relevant changes (faciological and geochemical) that occurs across the SMS assemblage zone depositions is illustrated in Figure 3. This model helps to identify the facies (dry mudflat - Dinodontosaurus and Santacruzodon AZ and sheet delta - Hyperodapedon and Riograndia AZ) and presents a geochemical synthesis of each particular biozone across the SMS.

Another data that could reinforce the environmental changes discussed here came from the fossil plants of the Cuyo basin, in Argentina. The Potrerillos Formation was deposited between 239 and 230.3 Ma. It is basically composed by an interleaving of peat and pyroclastic sediments reworked in conglomerates, sandstones and shales (Spalletti et al. 2008). This formation had its paleoflora analyzed by Artabe et al. (2007). They subdivided it into two Triassic biozones, the Yabeiella mereyesiaca - Scytophyllum bonettiae - Protophyllocladoxylon cortaderitaensis assemblage biozone (MBC) (Middle Triassic) and the Yabeiella brackebuschiana - Scytophyllum neuburgianum - Rhexoxylon piatnitzkyi assemblage biozone (BNP) (Upper Triassic). According to Artabe et al. (2007), the paleofloristic associations of Potrerillos (MBC and BNP) would be inserted in a dry subtropical zone of the southeast extratropical area of the Gondwana. This area should be exposed to megamonsoon regimes. This is corroborated by the presence of plant groups with seasonality adaptations and xeromorphic characteristics. According to Spalletti et al. (2005), the MBC and BNP paleofloras share species of Yabeiella and Scytophyllum genus. However, they differ in the occurrence of the genera Prtophyllocladoxylon (MBC) and Rhexoxylon (BNP), being the latter attributed to conifers, a group not closely related to the Corystosperms (Bodnar 2008). 
Shi et al. (2016) suggest that there is a correlation between Corystosperms and Ginkgo, a genus that continues until today. This similarity with living species allows to presume that, as in the actual Ginkgos, the Corystosperms (R. cortaderitaense) should be adapted to well-drained and high-recharging environments, like streams and river dikes (Royer et al. 2003). Fu et al. (1999) registered some Ginkgo occurrences in deciduous forests and loess deposits (well drained), whose soil's $\mathrm{pH}$ is around 5.0 to 5.5. Such favorable characteristics that allow the $R$. cortaderitaense's occurrence (acidity and welldrained soils) allow associating the BNP biozone (Cuyo's basin, Argentina) climate to the uppermost AZ from SMS,

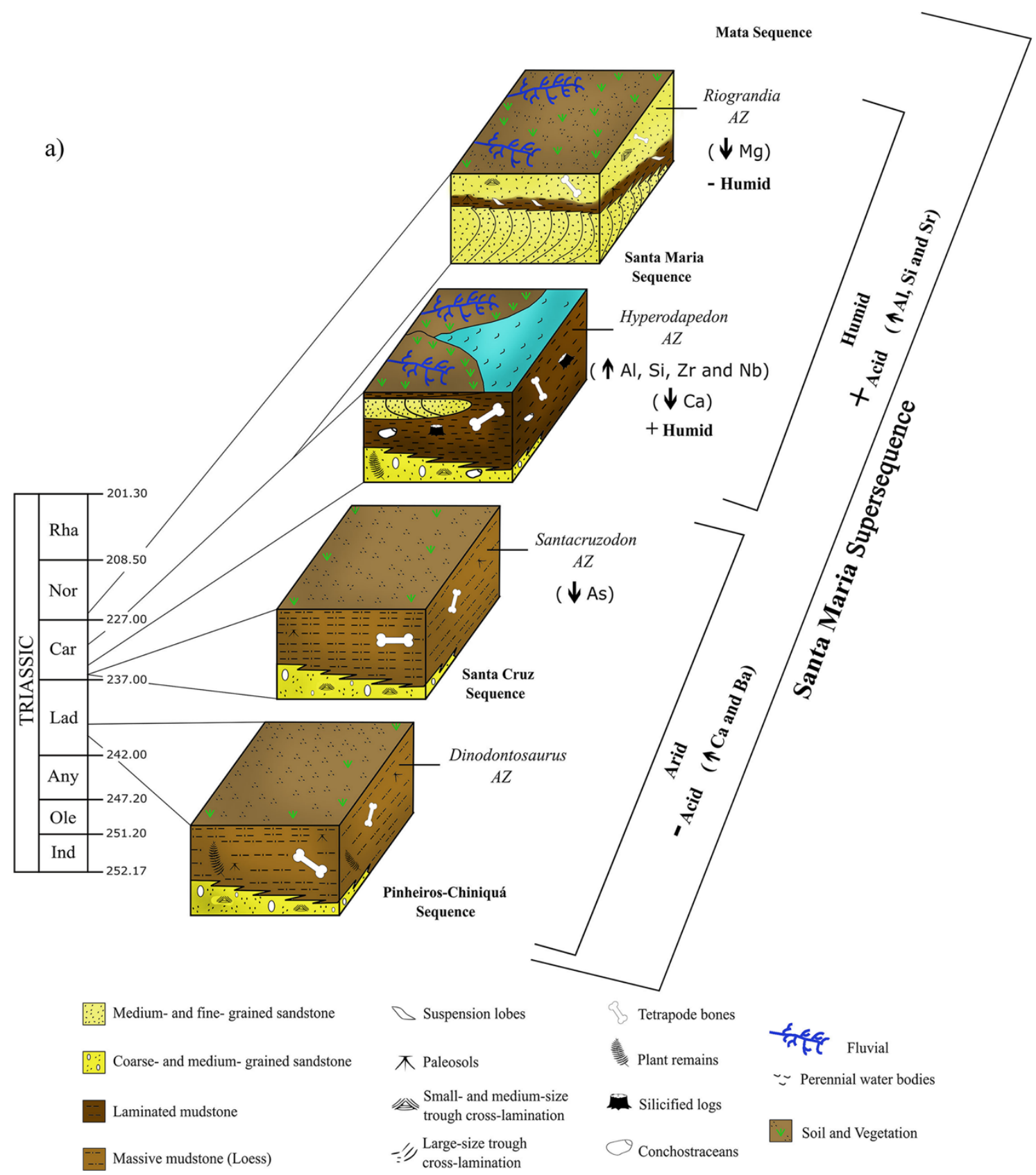

b)

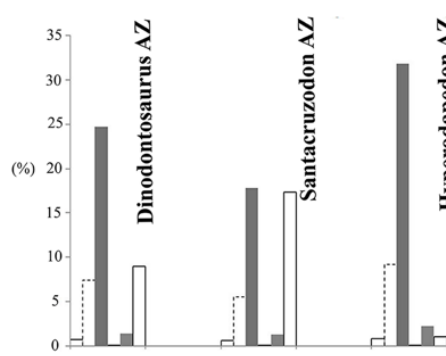

c)
Minor Elements

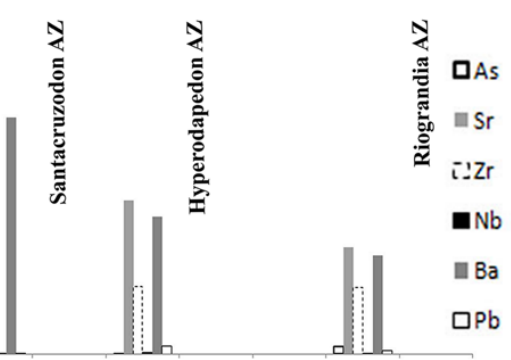

AZ: assemblage zone.

Figure 3. (A) A synthetic model with the most relevant changes (faciological and geochemical) that occurs across Santa Maria Supersequence AZ depositions. (B) Graphic with the major element's variation across the AZ. (C) Graphic with the trace element's variation across the AZ. 
particularly the Hyperodapedon AZ. These enlarge the influence zone of the biggest humidity event of the Carnian period (CPE) until the Argentines soils. This paleoclimatic condition of megamonsoon regimes is similar to that observed in the SMS region. Horn et al. (2018b) identified some climatic changes between the SMS biozones, from driest to wetter, in particular between the lowermost (Dinodontosaurus and Santacruzodon) and the uppermost (Hyperodapedon and Riograndia). Guerra-Sommer and Klepzig (2000) and Barboni and Dutra (2015) reported occurrences of leaves, Cuticule fragments and $e x$ situ fossil woods, with a predominance of the genus Dicroidium, in the Middle-Upper Triassic package (Passo das Tropas Member) paleoflora. This genus includes the Division Ginkgophyta. Such occurrences were first assigned to the Anisian-Ladinian age (Guerra-Sommer and Klepzig 2000), but recent studies comparing these ginkgophytes with those from different Gondwanan assemblages attributed a Carnian age for these Brazilian deposits (Barboni and Dutra 2015). This age is correlated to the Hyperodapedon's AZ dating. The occurrences of ex situ fossil woods can be interpreted as episodic flooding events, which corroborate with our hypothesis of a high humidity episode during the Hyperodapedon's AZ deposition. This work uses geochemical data obtained from vertebrate fossils and their sedimentary matrices to verify the climatic changes, unlike the Potrerillos Formation observations that used the conglomerate deposition as a criterion for the biozones (MBC and BNP) delimitation (indicating high energy flows, maybe related to a humidity peak). Subtle climatic changes are also recorded in SMS from faciological studies (gradation from loess deposits to underwater deposits) carried out by Horn et al. (2018a, 2018b).

Another data source that indicates a rise in humidity at the beginning of the Upper Triassic came from the particle size analysis made by the authors with rock samples from the analyzed biozones. It was observed an increase in the clay and sand percentages toward the top of the SMS package. This reinforces the idea that the uppermost $\mathrm{AZ}$ of this sequence were wetter than the basal ones. Besides the clay and sand content increase, the permanence of high silt percentages (above 80\%) are highlighted, especially in the thicker fractions, even in the wetter biozones. Thus, is suggests that the leading sediment supplier, in all biozones, was the wind, in a peridesertic context. In the lowermost AZ (Dinodontosaurus and Santacruzodon), the silt was deposited under massive layers (loess). On the other hand, the uppermost's (Hyperodapedon and Riograndia), the dust brought by the wind was reworked by the water, generating laminated deposits.

\section{CONCLUSIONS}

Throughout depositional evolution of the SMS, there was a change in the facies association, from dry mudflat facies (Pinheiros-Chiniquá and Santa Cruz Sequences) to sheet delta facies (Candelária Sequence). This facies change followed by geochemical variations record the passage from more basic conditions (characterized by the highest values of $\mathrm{Ca}$ and Ba of the Dinodontosaurus and Santacruzodon AZ) to a more acid environment (characterized by the highest percentages of $\mathrm{Al}, \mathrm{Si}$, and $\mathrm{Sr}$ of the Hyperodapedon and Riograndia AZ). This set of evidence points to a record of the CPE also for the SW portion of the Gondwana. The sedimentary matrices of the Santacruzodon AZ can be diagnosed by the low contents of As. The sediments of the Hyperodapedon $\mathrm{AZ}$, in their turn, are differentiated by the high contents of $\mathrm{Al}, \mathrm{Si}, \mathrm{Ti}, \mathrm{Fe}, \mathrm{Ni}, \mathrm{Rb}, \mathrm{Zr}$, and $\mathrm{Nb}$ and the low values of $\mathrm{F}, \mathrm{P}$, and Ca. The Riograndia AZ's sediments can be individualized by their low content of $\mathrm{Mg}$. The low contents of $\mathrm{Mg}$ and $\mathrm{Al}$ observed in Riograndia AZ attest a wetter period in this SMS biozone. However, if compared with the high contents of $\mathrm{Al}, \mathrm{Si}$, and Fe recorded in the Hyperodapedon AZ's sediments, it is possible to conclude that the highest humidity peak of the SMS is associated to this AZ. This hypothesis is more plausible, since sediments that are relatively enriched in $\mathrm{Si}, \mathrm{Al}$, and $\mathrm{Fe}$ used to be more mature (sediments exposed for very long periods of intense weathering, could be their soil profile leaching) than those with $\mathrm{Mg}$ and $\mathrm{Al}$. Therefore, the studied section records a high humidity episode, in the uppermost AZ of the SMS (Carnian) that could be related to the global event named CPE.

In addition, the geochemical study of the assemblage zones of the SMS shows that these biozones could be used as a stratigraphic element of correlation due to their characteristic geochemical compositions. However, due to the chemical heterogeneity observed in the studied samples, it is considered important to continue the studies in this area. More samples need to be analyzed in order to precisely determine the content variations of these elements across the AZ.

More detailed studies of geochemical variations of the fossiliferous of the studied AZ are needed. A paleofloristic study, similar to those made in Argentina, can also be performed. The particle size studies also need a refinement, in order to verify how the global paleoclimatic variations can influence the facies and AZ genesis in the Santa Maria Supersequence.

\section{ACKNOWLEDGMENTS}

This work is the end product of L. Corecco's Master's degree dissertation by the Programa de Pós-graduação em Geociências, of Instituto de Geociências, at Universidade Federal do Rio Grande do Sul. This study was financed, in part, by the Coordenação de Aperfeiçoamento de Pessoal de Nível Superior - Brasil (CAPES) - Finance Code 001, granting the scholarship for this student and, in part, by research project No. 476868/2010-6 attached to the Conselho Nacional de Desenvolvimento Científico e Tecnológico (CNPq), led by Dra. Marina Bento Soares. We also thank professors Paulo Alves de Souza and Claiton Marlon dos Santos Scherer; PhDs Bruno Ludovico Dihl Horn and Heitor Roberto Dias Francischini, as well as to the doctoral students Mauricio Rodrigo Schmitt, Francesco Battista, Voltaire Dutra Paes Neto, and Tomaz Panceri Melo for their helpful discussions about the theme. 


\section{ARTICLE INFORMATION}

Manuscript ID: 20190014. Received on: 02/23/2020. Approved on: 08/13/2020.

L.C., V.P.P., and C.L.S. wrote the first draft of the manuscript. L.C. prepared Figures 1, 2, and 3. L.C., C.L.S., and M.B.S. revised Santa Maria Supersequence geology and biostratigraphy. V.P.P., C.L.S., and M.B.S. revised and improved the manuscript through corrections and suggestions before submission.

Competing interests: The authors declare no competing interests.

\section{REFERENCES}

Anders E., Grevesse N. 1989. Abundances of the elements: meteoritic and solar. Geochimica et Cosmochimica Acta, 53(1):197-214. https://doi. org/10.1016/0016-7037(89)90286-X

Artabe A.E., Morel E.M., Ganuza D.G., Zavattieri A.M., Spalletti L.A. 2007. La paleoflora triásica de Potrerillos, provincia de Mendoza, Argentina. Ameghiniana, 44(2):279-301.

Barboni R., Dutra T.L. 2015. First record of Ginkgo-related fertile organs (Hamshawvia, Stachyopitys) and leaves (Baiera, Sphenobaiera) in the Triassic of Brazil, Santa Maria formation. Journal of South American Earth Sciences, 63:417-435. https://doi.org/10.1016/j.jsames.2015.08.001

Benton M.J. 1986. More than one event in the Late Triassic mass extinction. Nature, 321(6073):857-861. https://doi.org/10.1038/321857a0

Benton M.J. 2018. Hyperthermal-driven mass extinctions: killing models during the Permian-Triassic mass extinction. Philosophical Transactions of the Royal Society A, 376(2130):1-19. https://doi.org/10.1098/rsta.2017.0076

Benton M.J., Bernardi M., Kinsella C. 2018. The Carnian Pluvial Episode and the origin of dinosaurs. Journal of the Geological Society, 175(6):10191026. https://doi.org/10.1144/jgs2018-049

Benton M.J., Newell A.J. 2014. Impacts of global warming on Permo-Triassic terrestrial ecosystems. Gondwana Research, 25(4):1308-1337. https://doi. org/10.1016/j.gr.2012.12.010

Bland J.M., Altman D.G. (eds.). 1996. Statistics notes: measurement error. BMJ, 313(7047):744. https://doi.org/10.1136/bmj.313.7059.744

Bodnar J. 2008. Rhexoxylon cortaderitaense (Menéndez) comb. nov., a species of permineralized stems newly assigned to the Corystospermaceae, from the Triassic of Argentina. Alcheringa, 32(2):171-190. https://doi. org/10.1080/03115510801928338

Brookins D.G. (ed.). 1988. Eh-pH diagrams for geochemistry. New York: Springer-Verlag, $176 \mathrm{p}$.

Cheng C., Li S., Xie X., Cao T., Manger W.L., Busbey A.B. 2019. Permian carbon isotope and clay mineral records from the Xikou section, Zhen'an, Shaanxi Province, central China: climatological implications for the easternmost Paleo-Tethys. Palaeogeography, Palaeoclimatology, Palaeoecology, 514:407-422. https://doi.org/10.1016/j.palaeo.2018.10.023

Fu L., Li N., Elias T.S., Mill R.R. 1999. Sections of Cephalotaxaceae and Pinaceae. In: Wu Z., Raven P.H. (eds.). Flora of China, 4. Beijing: Science Press, St. Louis, Missouri Botanical Garden, p. 11-109.

Furin S., Preto N., Rigo M., Roghi G., Gianolla P., Crowley J.L., Bowring S.A. 2006. High-precision U-Pb zircon age from the Triassic of Italy: Implications for the Triassic time scale and the Carnian origin of calcareous nannoplankton and dinosaurs. Geology, 34(12):1009-1012. https://doi.org/10.1130/G22967A.1

Gromet L.P., Haskin L.A., Korotev R.L., Dymek R.F. 1984. The North American Shale composite: its compilation, major and trace element characteristics. Geochimica et Cosmochimica Acta, 48(12):2469-2482. https://doi.org/10.1016/0016-7037(84)90298-9

Guerra-Sommer M., Klepzig M.C. 2000. The Triassic taphoflora from Parana Basin, southern Brazil: an overview. Revista Brasileira de Geociências, 30(3):481-485.

Horn B.L.D. 2013. A fossildiagênese do pacote Meso-Neotriássico do RS. MS Dissertation, Instituto de Geociências, Universidade Federal do Rio Grande do Sul, Porto Alegre, $64 \mathrm{p}$.

Horn B.L.D., Goldberg K., Schultz C.L. 2018a. A loess deposit in the Late Triassic of southern Gondwana, and its significance to global paleoclimate. Journal of South American Earth Sciences, 81:189-203. https://doi. org/10.1016/j.jsames.2017.11.017
Horn B.L.D., Goldberg K., Schultz C.L. 2018b. Interpretation of massive sandstones in ephemeral fluvial settings - a case study from the upper Candelaria Sequence (Upper Triassic, Paraná Basin, Brazil). Journal of South American Earth Sciences, 81:108-121. https://doi.org/10.1016/j.jsames.2017.10.009

Horn B.L.D., Melo T.M., Schultz C.L., Philipp R.P., Kloss H.P., Goldberg K. 2014. A New third-order sequence stratigraphic framework applied to the Triassic of the Paraná Basin, Rio Grande do Sul, Brazil, based on structural, stratigraphic and paleontological data. Journal of South American Earth Sciences, 55:123-132. https://doi.org/10.1016/j.jsames.2014.07.007

Langer M.C., Ramezani J., Da Rosa A. 2018. U-Pb age constraints on dinosaur rise from South America. Gondwana Research, 57:133-140. https://doi.org/10.1016/j.gr.2018.01.005

Langer M.C., Ribeiro A.M., Schultz C.L., Ferigolo J. 2007. The continental tetrapod-bering Triassic of South Brazil. New Mexico Museum of Natural History and Science Bulletin, 41:201-218.

Lucas S.G., Tanner L.H. 2018. The missing mass extinction at the TriassicJurassic boundary In: Tanner L.H. (ed.). The Late Triassic World: Earth in a time of transition. Cham: Springer, p. 721-785.

Martinelli A.G., Kammerer C.F., Melo T.P., Paes Neto V.D., Ribeiro A.M., Da-Rosa A.A.S., Schultz C.L., Soares M.B. 2017. The African cynodont Aleodon (Cynodontia, Probainognathia) in the Triassic of southern Brazil and its biostratigraphic significance. PloS One, 12(6):e0177948. https:// doi.org/10.1371/journal.pone.0177948

Milani E.J. 1997. Evolução tectono-estratigráfica da Bacia do Paraná e seu relacionamento com a geodinâmica fanerozóica do Gondwana Sul-ocidental. $\mathrm{PhD}$ Thesis, Instituto de Geociências, Universidade Federal do Rio Grande do Sul, Porto Alegre, $420 \mathrm{p}$.

Milani E.J., Faccini U.F., Scherer C.M., Araújo L.M., Cupertino J.A. 1998. Sequences and stratigraphic hierarchy of the Paraná Basin (Ordovician to Cretaceous), southern Brazil. Boletim do Instituto de Geociências USP. Série Científica, 29:125-173. http://dx.doi.org/10.11606/issn.2316-8986. v29i0p125-173

Nagarajan R., Madhavaraju J., Nagendra R., Armstrong-Altrin J.S., Moutte J. 2007. Geochemistry of Neoproterozoic shales of the Rabanpalli Formation, Bhima Basin, northern Karnataka, southern India: implications for provenance and paleoredox condition. Revista Mexicana de Ciencias Geológicas, 24(2):150-160.

Ogg J.G. 2015. The mysterious Mid-Carnian "Wet Intermezzo" Global Event. Journal of Earth Science, 26(2):181-191. https://doi.org/10.1007/ s12583-015-0527-x

Paim P.A.V. 2020. Elementos terras raras em ossos fósseis do Permo-triássico da Bacia do Paraná (Brasil). MS Dissertation, Instituto de Geociências, Universidade Federal do Rio Grande do Sul, Porto Alegre, 149 p.

Pavanatto A.E.B., Pretto F.A., Kerber L., Müller R.T., Da-Rosa A.A.S., Diasda-Silva S. 2018. A new Upper Triassic cynodont-bearing fossiliferous site from southern Brazil, with taphonomic remarks and description of a new traversodontid taxon. Journal of South American Earth Sciences, 88:179-196. https://doi.org/10.1016/j.jsames.2018.08.016

Philipp R.P., Schultz C.L., Kloss H.P., Horn B.L.D., Soares M.B., Basei M.A.S. 2018. Middle Triassic SW Gondwana paleogeography and sedimentary dispersal revealed by integration of stratigraphy and U-Pb zircon analysis: the Santa Cruz Sequence, Paraná Basin, Brazil. Journal of South American Earth Sciences, 88:216-237. https://doi.org/10.1016/j.jsames.2018.08.018

Preto N., Hinnov L.A. 2003. Unravelling the origin of shallowwater cyclothems in the Upper Triassic Dürrenstein Fm. (Dolomites, Italy). Journal of Sedimentary Research, 73(5):774-789. http://dx.doi. org/10.1306/030503730774 
Preto N., Kustatscher E., Wignall P.B. 2010. Triassic climates-state of the art and perspectives. Palaeogeography, Palaeoclimatology, Palaeoecology, 290(1-4):1-10. https://doi.org/10.1016/j.palaeo.2010.03.015

Prochnow S.J., Nordt L.C., Atchley S.C., Hudec M.R. 2006. Multi-proxy paleosol evidence for Middle and Late Triassic climate trends in eastern Utah. Palaeogeography, Palaeoclimatology, Palaeoecology, 232(1):53-72. https://doi.org/10.1016/j.palaeo.2005.08.011

Reichel M., Schultz C.L., Pereira V.P. 2005. Diagenetic pattern of the vertebrate fossils from the Traversodontid Biozone, Santa Maria Formation (middle Triassic of Rio Grande do Sul, southren Brazil). Revista Brasileira de Paleontologia, 8(3):173-180.

Rigo M., Preto N., Roghi G., Tateo F., Mietto P. 2007. A rise in the carbonate compensation depth of western Tethys in the Carnian: deep-water evidence for the Carnian Pluvial Event. Palaeogeography, Palaeoclimatology, Palaeoecology, 246(2-4):188-205. https://doi.org/10.1016/j.palaeo.2006.09.013

Royer D.L., Hickey L.J., Wing S.L. 2003. Ecological conservatism in the "living fossil" Ginkgo. Paleobiology, 29(1):84-104. https://doi. org/10.1666/0094-8373(2003)029\%3C0084:ECITLF\%3E2.0.CO;2

Schmitt M.R., Martinelli A.G., Melo T.P., Soares M.B. 2019. On the occurrence of the traversodontid Massetognathus ochagaviae (Synapsida, Cynodontia) in the early late Triassic Santacruzodon Assemblage Zone (Santa Maria Supersequence, southern Brazil): Taxonomic and biostratigraphic implications. Journal of South American Earth Sciences, 93:36-50. https://doi.org/10.1016/j.jsames.2019.04.011

Schultz C.L., Scherer C.S.M., Barberena M.C. 2000. Biostratigraphy of southern Brazilian Middle-Upper Triassic. Revista Brasileira de Geociências, 30(3):495-498.

Sheldon N.D., Tabor N.J. 2009. Quantitative paleoenvironmental and paleoclimatic reconstruction using paleosols. Earth-Science Reviews, 95(12):1-52. https://doi.org/10.1016/j.earscirev.2009.03.004

Shi G., Leslie A.B., Herendeen P.S., Herrera F., Ichinnorov N., Takahashi M., Knopf P., Crane P.R. 2016. Early Cretaceous Umkomasia from Mongolia: implications for homology of corystosperm cupules. New Phytologist, 210(4):1418-1429. https://doi.org/10.1111/nph.13871
Simms M.J., Ruffell A.H. 1989. Synchroneity of climatic change and extinctions in the Late Triassic. Geology, 17(3):265-268. https://doi. org/10.1130/0091-7613(1989)017\%3C0265:SOCCAE\%3E2.3.CO;2

Simms M.J., Ruffell A.H. 1990. Climatic and biotic change in the late Triassic. Journal of the Geological Society of London, 147(2):321-327. https://doi.org/10.1144/gsjgs.147.2.0321

Simms M.J., Ruffel A.H., Johnson L.A. 1995. Biotic and climatic changes in the Carnian (Triassic) of Europe and adjacent areas. In: Fraser N.C., Sues H.D. (eds.). The Shadow of the Dinosaurs: Early Mesozoic Tetrapods. Cambridge: Cambridge University Press, p. 352-365.

Soares M.B., Schultz C.L., Horn B.L.D. 2011. New information on Riograndia guaibensis Bonaparte, Ferigolo \& Ribeiro, 2001 (Eucynodontia, Tritheledontidae) from the Late Triassic of southern Brazil: anatomical and biostratigraphic implications. Anais da Academia Brasileira de Ciências, 83(1):329-354. http://dx.doi.org/10.1590/S0001-37652011000100021

Spalletti L.A., Fanning M., Rapel A.C.W. 2008. Dating the Triassic continental rift in the southern Andes: the Potrerillos Formation, Cuyo basin, Argentina. Geologica Acta, 6(3):267-283.

Spalletti L.A., Morel E.M., Artabe A.E., Zavattieri A.M., Ganuza D. 2005. Estratigrafía, facies y paleoflora de la sucesión triásica de Potrerillos, Mendoza, República Argentina. Revista Geológica de Chile, 32(2):249-272. http://dx.doi.org/10.4067/S0716-02082005000200005

Walker H. (ed.). 1931. Studies in the History of the Statistical Method. Baltimore: Williams \& Wilkins Co., 229 p.

White W.M. 2013. Aquatic chemistry. In: White W.M. (ed.). Geochemistry. Chichester: Wiley-Blackwell, p. 217-265.

ZengZ.,Zhu H., Yang X., Zeng H., Hu X., Xia C. 2019. The Pangaea megamonsoon records: Evidence from the Triassic Mungaroo Formation, northwest shelf of Australia.Gondwana Research,69:1-24.https://doi.org/10.1016/j.gr.2018.11.015

Zerfass H., Lavina E.L., Schultz C.L., Garcia A.J., Faccini U.F., Chemale Jr. F. 2003. Sequence stratigraphy of continental Triassic strata of southernmost Brazil: a contribution to southwestern Gondwana palaeogeography and palaeoclimate. Sedimentary Geology, 161(1-2):85-105. https://doi. org/10.1016/S0037-0738(02)00397-4 